\title{
Antibodies Targeting Chemokine Receptors CXCR4 and ACKR3
}

\author{
Vladimir Bobkov, Marta Arimont, Aurélien Zarca, Timo W.M. De Groof, Bas van der Woning, \\ Hans de Haard, and Martine J. Smit
}

Division of Medicinal Chemistry, Amsterdam Institute for Molecules Medicines and Systems, Vrije Universiteit Amsterdam, Amsterdam, The Netherlands (V.B., M.A., A.Z., T.W.M.D.G., M.J.S.); and argenx BVBA, Zwijnaarde, Belgium (V.B., B.W., H.H.)

Received April 22, 2019; accepted July 3, 2019

\section{ABSTRACT}

Dysregulation of the chemokine system is implicated in a number of autoimmune and inflammatory diseases, as well as cancer. Modulation of chemokine receptor function is a very promising approach for therapeutic intervention. Despite interest from academic groups and pharmaceutical companies, there are currently few approved medicines targeting chemokine receptors. Monoclonal antibodies (mAbs) and antibody-based molecules have been successfully applied in the clinical therapy of cancer and represent a potential new class of therapeutics targeting chemokine receptors belonging to the class of $G$ protein-coupled receptors (GPCRs). Besides conventional mAbs, single-domain antibodies and antibody scaffolds are also gaining attention as promising therapeutics. In this review, we provide an extensive overview of mAbs, singledomain antibodies, and other antibody fragments targeting
CXCR4 and ACKR3, formerly referred to as CXCR7. We discuss their unique properties and advantages over smallmolecule compounds, and also refer to the molecules in preclinical and clinical development. We focus on singledomain antibodies and scaffolds and their utilization in GPCR research. Additionally, structural analysis of antibody binding to CXCR4 is discussed.

\section{SIGNIFICANCE STATEMENT}

Modulating the function of GPCRs, and particularly chemokine receptors, draws high interest. A comprehensive review is provided for monoclonal antibodies, antibody fragments, and variants directed at CXCR4 and ACKR3. Their advantageous functional properties, versatile applications as research tools, and use in the clinic are discussed.

\section{Introduction}

CXCR4 and ACKR3: Role in Physiology and Diseases. Chemokines and chemokine receptors play key roles in immune system homeostasis, controlling the activation, differentiation, migration, and survival of leukocytes and other hematopoietic cells (Scholten et al., 2012). Due to their role in leukocyte migration, the chemokine receptor system is an important mediator of inflammation. Prolonged or deregulated expression of chemokines or chemokine receptors promotes abnormal infiltration of leukocytes into inflamed tissue. This may result in inflammation, autoimmune diseases, tumor growth, survival, and metastasis (Scholten et al., 2012). Most chemokine receptors, belonging to the superfamily of G protein-coupled receptors (GPCRs), activate G protein-dependent signaling pathways upon agonist binding. However, there are some chemokine receptors that signal via

This research was funded by the European Union's Horizon 2020 Marie Skłodowska-Curie Actions Program under ONCORNET Grant 641833

https://doi.org/10.1124/mol.119.116954.
$\mathrm{G}$ protein-independent systems and are, therefore, referred to as atypical chemokine receptors (Nibbs and Graham, 2013). CXCR4 activates the $\mathrm{G}_{\mathrm{i}}$ family of heterotrimeric $\mathrm{G}$ proteins, while ACKR3, previously known as CXCR7, signals in a G protein-independent and $\beta$-arrestin-dependent manner. ACKR3 downregulates CXCR4 signaling by either scavenging its ligand CXCL12 or forming heterodimers with CXCR4 (Rajagopal et al., 2010); there may also be crosstalk between CXCR4 and ACKR3 upon ligand binding that is mediated by intracellular signaling effectors (Zabel et al., 2009).

CXCR4 and ACKR3 have been widely studied in relation to their role in a large number of diseases. CXCR4 was the first human immunodeficiency virus (HIV) coreceptor discovered and has since then become an interesting target for the treatment of AIDS (De Clercq, 2003). X4 HIV strains bind to CD4 and CXCR4 through the envelope glycoprotein gp120 to infect the target cell (Murphy and Heusinkveld, 2018). Mutations truncating the C-terminus of CXCR4 also cause the rare immunodeficiency warts, hypogammaglobulinemia,

ABBREVIATIONS: ADCC, antibody-dependent cell-mediated cytotoxicity; CDC, complement-dependent cytotoxicity; CDR, complementarity determining region; CGRP, calcitonin gene-related peptide; ECL, extracellular loop; Fab, antigen-binding fragment; Fc, fragment crystallizable; FDA, Food and Drug Administration; GPCR, G protein-coupled receptor; mAb, monoclonal antibody; Nb, nanobody. 
infections, and myelokathexis syndrome. The CXCR4-CXCL12 axis is also implicated in chronic inflammatory diseases such as asthma and rheumatoid arthritis (Tamamura et al., 2004). Multiple cancer cells show elevated expression of CXCR4, including breast, ovarian, and prostate cancer cells, melanomas, gliomas, neuroblastomas, osteosarcomas, leukemia, T- and B-cell lymphomas, colorectal, pancreatic, and uterine cancers, among others (Peled et al., 2012). ACKR3 expression is also increased in a number of cancer types including leukemia, breast, pancreatic, colon, and lung (Miao et al., 2007; Melo et al., 2014; D'Alterio et al., 2016; Guo et al., 2016). Both receptors are involved in different stages of tumorigenesis including growth, survival, and metastasis, according to in vitro and in vivo experimental data (Burns et al., 2006; Peled et al., 2012; Scholten et al., 2012; Teixidó et al., 2018). Thus, a specific blockage of CXCR4 and/or ACKR3 function has a great potential for clinical therapy of cancer and other disorders. Antibodies and their fragments can be ideal candidates for such clinical interventions and serve as important tools in fundamental research.

Monoclonal Antibodies and Their First Approvals for Targeting GPCRs. In 1985, the United States Food and Drug Administration (FDA) approved the first monoclonal antibody (mAb) directed against CD3, muromonab (Orthoclone OKT3), for the treatment of kidney transplant rejection (Smith, 1996). Since then, $76 \mathrm{mAbs}$ have received marketing approval by the European Medicines Agency and FDA, with

A

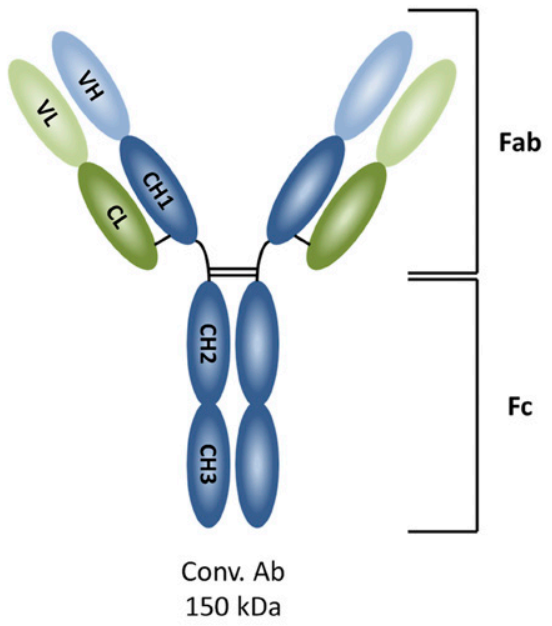

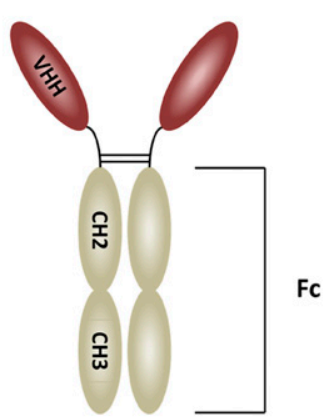

HCAb $90 \mathrm{kDa}$
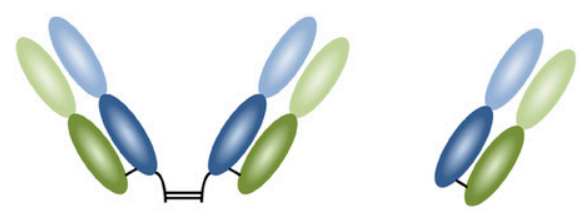

$\mathrm{F}\left(a b^{\prime}\right) 2$

$\mathrm{F}(\mathrm{ab})$

$110 \mathrm{kDa}$

$50 \mathrm{kDa}$

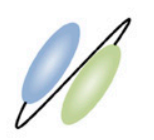

ScFv

$25 \mathrm{kDa}$

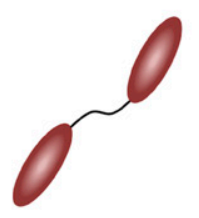

Biv. $\mathrm{Nb}$

$30 \mathrm{kDa}$

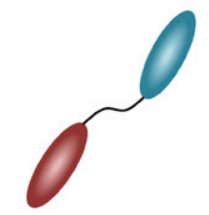

Bispec. $\mathrm{Nb}$ $30 \mathrm{kDa}$
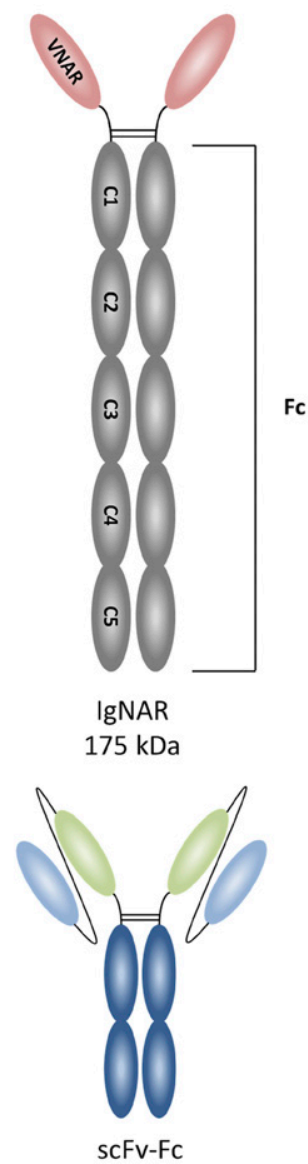

$100 \mathrm{kDa}$

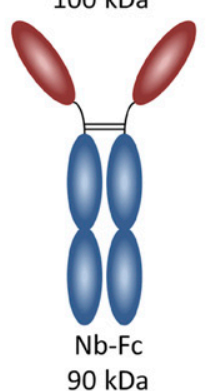

Fig. 1. Overview of antibody formats. (A) Schematic representation of the structure of a conventional antibody (Conv. Ab), heavy chain-only antibody (HCAb), and immunoglobulin new antigen receptor (IgNAR). The antibodies consist of constant domains [constant heavy (CH) and constant light (CL)] and variable domains [variable heavy $(\mathrm{VH})$, variable light (VL), variable heavy chain region of a heavy chain-only antibody (VHH), or variable fragment of immunoglobulin new antigen receptor (VNAR)], which make up the Fc region and Fab domains. (B) Overview of commonly used fragments derived from Conv. Abs, HCAbs, or IgNARs. Bispec. Nb, bispecific nanobody; Biv. Nb, bivalent nanobody; Nb, nanobody; Nb-Fc, nanobody-Fc fusion protein; scFv, single-chain variable fragment. 
around $30 \mathrm{mAbs}$ approved for oncological indications (http:// www.ema.europa.eu, www.fda.gov; as of April 2019). mAbs and antibody-based therapeutics is a relatively young but fastgrowing field with approximately 30 candidates in late-stage clinical trials for cancer therapy and many more in earlier phases of development, indicating a further increase in approvals in the upcoming years (Kaplon and Reichert, 2018).

Antibodies are normally produced by B-cells of the immune system to regulate immune response and specifically bind and neutralize foreign pathogens and microbes. Specific target recognition is mediated by variable fragments located on the ends of two antigen-binding fragment (Fab) arms composed of heavy and light chains (Figs. 1 and 2). Fabs are connected to the fragment crystallizable $(\mathrm{Fc})$ region, and the resulting molecule features a Y-shaped heterotetrameric structure with an approximate molecular weight of $150 \mathrm{kDa}$. In 1975, Köhler and Milstein introduced the first technique for isolating murine mAbs from hybridomas, triggering development of antibodies for academic research, clinical diagnostics, and eventually therapeutics, to date representing an industry with billion-euro revenues (Köhler and Milstein, 1975). Afterward, several methods were introduced to generate fully human mAbs to overcome immunogenicity issues associated with rodent or humanized antibodies. Examples include in vitro antibody display technologies or transgenic animals modified to have the human antibody repertoire (Lonberg et al., 1994; Boder and Wittrup, 1997; de Haard et al., 1999; Hanes et al., 2000). Currently, multiple platforms are in use by biotech companies and research groups to select antibodies and antibody fragments with desired specificity and affinity against targets of interest, including GPCRs.

Historically, GPCRs are targeted with small-molecule drugs, some of which face issues including fast receptor dissociation, poor oral bioavailability, and other pharmacokinetic aspects (Pease and Horuk, 2012). Currently, there are only two antibodies against GPCRs approved for clinical therapy. One is mogamulizumab (Poteligeo) targeting CCR4, which received the first marketing approval in 2012 in Japan for the treatment of CCR4-positive adult T-cell leukemia/ lymphoma (Beck and Reichert, 2012). In May 2018, the FDA approved another GPCR-targeting $\mathrm{mAb}$, erenumab (Aimovig), a fully human antagonistic antibody against the calcitonin gene-related peptide (CGRP) receptor for prevention of migraine (Dolgin, 2018). Erenumab is a highly potent antibody, and in comparison with small-molecule compounds targeting the CGRP receptor, e.g., telcagepant [N-[(3R,6S)-6-(2,3difluorophenyl)-2-oxo-1-(2,2,2-trifluoroethyl)azepan-3-yl]-4(2-oxo-3H-imidazo[4,5-b]pyridin-1-yl)piperidine-1-carboxamide], it offers greater specificity with no measurable activity on other receptors in the family, thus reducing possible off-target effects (Walker et al., 2015; Shi et al., 2016). CGRP has an extensive binding epitope on the receptor. Therefore, a broad coverage of the extracellular sites with multiple interactions on both subunits of the CGRP receptor by erenumab can offer superior specificity and potency in competing with CGRP over small-molecule analogs (Hollenstein et al., 2014; Shi et al., 2016). Application of small-molecule CGRP receptor antagonists in clinical trials was associated with liver toxicity and was discontinued (Moore and Salvatore, 2012). Antibodies, erenumab included, are mostly eliminated via proteolytic degradation in a liver- and renal-independent manner, which greatly reduces the risk of hepatotoxicity and drug-drug interactions (Wu and Dall'Acqua, 2005; Silberstein et al., 2015). Additionally, the overall prolonged blood half-life of antibodies allows less frequent administration of erenumab, which has advantages for prophylactic treatment of migraine and better therapy adherence (Raffaelli and Reuter, 2018).

The limited number of currently available therapeutic antibodies targeting GPCRs may in part be explained by technical difficulties during the antibody development phase. Those difficulties have been reflected in several reports demonstrating poor specificity or reactivity of a few GPCRdirected commercial antibodies, including some against ACKR3 (Bodei et al., 2009; Berahovich et al., 2010). This might in part be explained by the usage of short synthetic

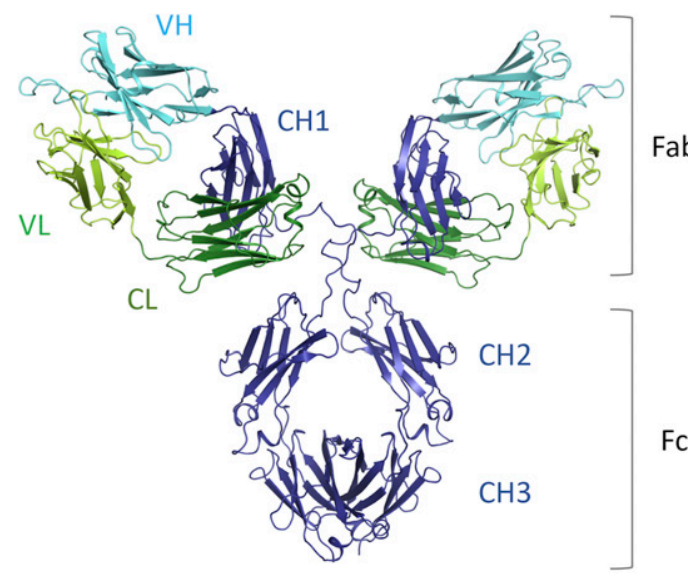

Conv. Ab

$\sim 1300$ aa

Fab

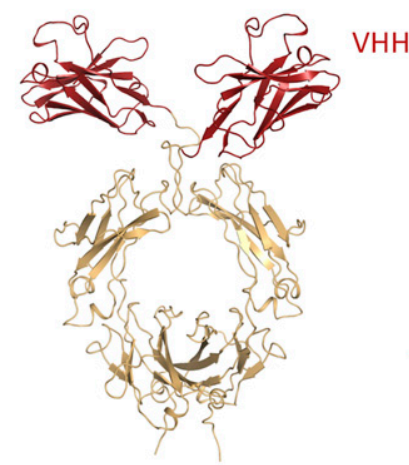

$\begin{aligned} & \mathrm{Nb}-\mathrm{Fc} \\ & \sim 700 \text { aa }\end{aligned}$

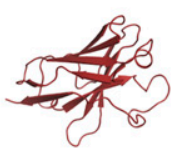

$\mathrm{Nb}$

$\sim 120$ aa

Fig. 2. Three-dimensional models of a conventional antibody (left), a nanobody-Fc fusion protein (middle), and a nanobody (right). These models were produced by homology modeling in the software modeler (version 9.15) (Webb and Sali, 2017) and are based on the crystal structure with Protein Data Bank identifier: 1HZH (Saphire et al., 2001) as a template. The sequence of the nanobody corresponds to the Nb VUN400 (Van Hout et al., 2018). CH, constant heavy; CL, constant light; Conv. Ab, conventional antibody; VH, variable heavy; VL, variable light; VHH, variable heavy chain region of a heavy chain-only antibody. 
peptide fragments as antigens for immunization and/or material for antibody selection. Such peptides lack important post-translational modifications and, overall, hardly represent unique conformational features of the target GPCR. As a result, a final antibody can possibly bind multiple antigens sharing similar linear epitopes or have poor affinity. Caution is needed in experimental application and data interpretation using such antibodies (Kirkpatrick, 2009). In addition, several validation techniques, including the disappearance of staining in the target knockout animals and reduction of staining upon knockdown approaches (Michel et al., 2009) or evaluation of specific functionality on a panel of closely related receptors (Griffiths et al., 2016), are necessary to ensure the antibodies are specifically targeting the receptor of interest.

Using GPCRs in physiologically relevant conformations during the antibody generation phase appears to be crucial for development of highly potent and specific therapeutic candidates, thus minimizing potential off-target effects. Purified forms of GPCRs are only available for a limited number of receptors. Additionally, stabilization of a purified receptor conformation with detergents is also required, which can mask extracellular epitopes needed for antibody binding (Hutchings et al., 2010). The transmembrane topology and absence of purified protein material necessitate usage of membranes, virus-like particles, or cells presenting a target receptor for immunization and/or phage display selection (Baribaud et al., 2001; Tamura and Chiba, 2009; Silence et al., 2014; Van Hout et al., 2018). As an alternative to live cell immunization, which often results in a broad off-target immune response, DNA immunization represents another approach for transmembrane receptors (van der Woning et al., 2016; Bobkov et al., 2018a). An additional limiting factor is generally the low surface expression levels of GPCRs.

In this review we will focus on the therapeutic mAbs, nanobodies (Nbs), and other functional fragments developed against CXCR4 and ACKR3. Information regarding other GPCR-targeting antibodies can be found in a recent review by Hutchings et al. (2017).

\section{Targeting CXCR4 and ACKR3 with Antibodies}

Given the key role of the CXCR4 and ACKR3 receptors in a variety of diseases, they have received increasing attention from academia and the pharmaceutical industry in relation to developing drugs that specifically target them. Despite considerable effort, there is only one small-molecule compound against CXCR4 that is approved by the FDA, Plerixafor (AMD3100, 1-[[4-(1,4,8,11-tetrazacyclotetradec-1-ylmethyl) phenyl]methyl]-1,4,8,11-tetrazacyclotetradecane)(Brave et al., 2010). As molecules for therapeutic intervention, antibodies can offer several benefits in comparison with small-molecule compounds (Table 1). Longer blood half-life, up to several weeks for IgG, can offer less-frequent patient dosing regimens in the treatment of certain conditions, e.g., in preventive therapy (Chames et al., 2009). Depending on the IgG subclass, mAbs can possess Fc domain-mediated effector functions that result in the elimination of target-expressing cells via antibody-dependent cell-mediated cytotoxicity (ADCC) and complement-dependent cytotoxicity (CDC) (Vidarsson et al., 2014). In the context of targeting chemokine receptors, proof of concept for this approach was demonstrated by mogamulizumab, a glyco-engineered mAb with enhanced ADCC activity that efficiently eliminates CCR4-overexpressing tumor cells (Ito et al., 2009). Multiple other Fc engineering approaches have been described for fine tuning the effector functions and blood half-life (Saxena and $\mathrm{Wu}, 2016$ ). Additionally, antibodies can be made as bispecific molecules to specifically recognize two different epitopes or as antibody-drug conjugates for the targeted delivery of cytotoxic agents, enabling additional therapeutic modalities (Beck et al., 2017; Godar et al., 2018).

In contrast to mogamulizumab, ulocuplumab (BMS-936564/ MDX1338) is a fully human IgG4 lacking ADCC and CDC effector functions. It is currently the most advanced antiCXCR4 therapeutic antibody in clinical trials, actively studied for the treatment of Waldenström's macroglobulinemia and acute myeloid leukemia (Table 2). Ulocuplumab binds to the extracellular loop 2 (ECL2) of CXCR4, prevents CXCL12 binding, and inhibits CXCL12-mediated signaling and cell

\section{TABLE 1}

Comparison of therapeutic antibodies and small-molecule compounds targeting GPCRs

\begin{tabular}{|c|c|}
\hline Antibody & Small Molecule \\
\hline \multicolumn{2}{|l|}{ General properties } \\
\hline Mostly antagonists & Antagonists, agonists, and allosteric modulators \\
\hline Preference for extracellular epitopes & Binding multiple pockets, including intracellular \\
\hline Administration mostly intravenous or subcutaneous & Oral administration possible \\
\hline Immunogenicity minimized by humanization & Low risk for immunogenicity \\
\hline Effector functions & No effector functions \\
\hline Longer serum half-life, reduced dosing frequency & Shorter serum half-life, variable dosing frequency \\
\hline Restricted blood-brain barrier penetration & Good blood-brain barrier penetration \\
\hline \multicolumn{2}{|l|}{ Development } \\
\hline High target expression during immunization and selection needed & Development not dependent on target expression \\
\hline Higher costs of development and manufacturing & Lower costs of development and manufacturing \\
\hline \multicolumn{2}{|l|}{ GPCR targeting } \\
\hline Possibility of targeting low-druggability GPCRs & Poor tractability, failed to target a variety of GPCRs (e.g., class B2, F) \\
\hline Enhanced selectivity and specificity & Lower selectivity, often target family-conserved binding sites \\
\hline Less off-target effects & Off-target effects \\
\hline \multicolumn{2}{|l|}{ Applications } \\
\hline $\begin{array}{l}\text { Easy to label and functionalize, e.g., bispecifics, fragments, and } \\
\text { conjugates }\end{array}$ & Challenging to label \\
\hline \multicolumn{2}{|c|}{ Clinical development } \\
\hline $\begin{array}{l}\text { Lower overall rate of attrition and higher transition rates at all stages of } \\
\text { development }\end{array}$ & Lower approval success rates \\
\hline
\end{tabular}


TABLE 2

Overview of monoclonal antibodies, nanobodies, and antibody-based fragments and scaffolds directed at and modulating CXCR4 and ACKR3 function

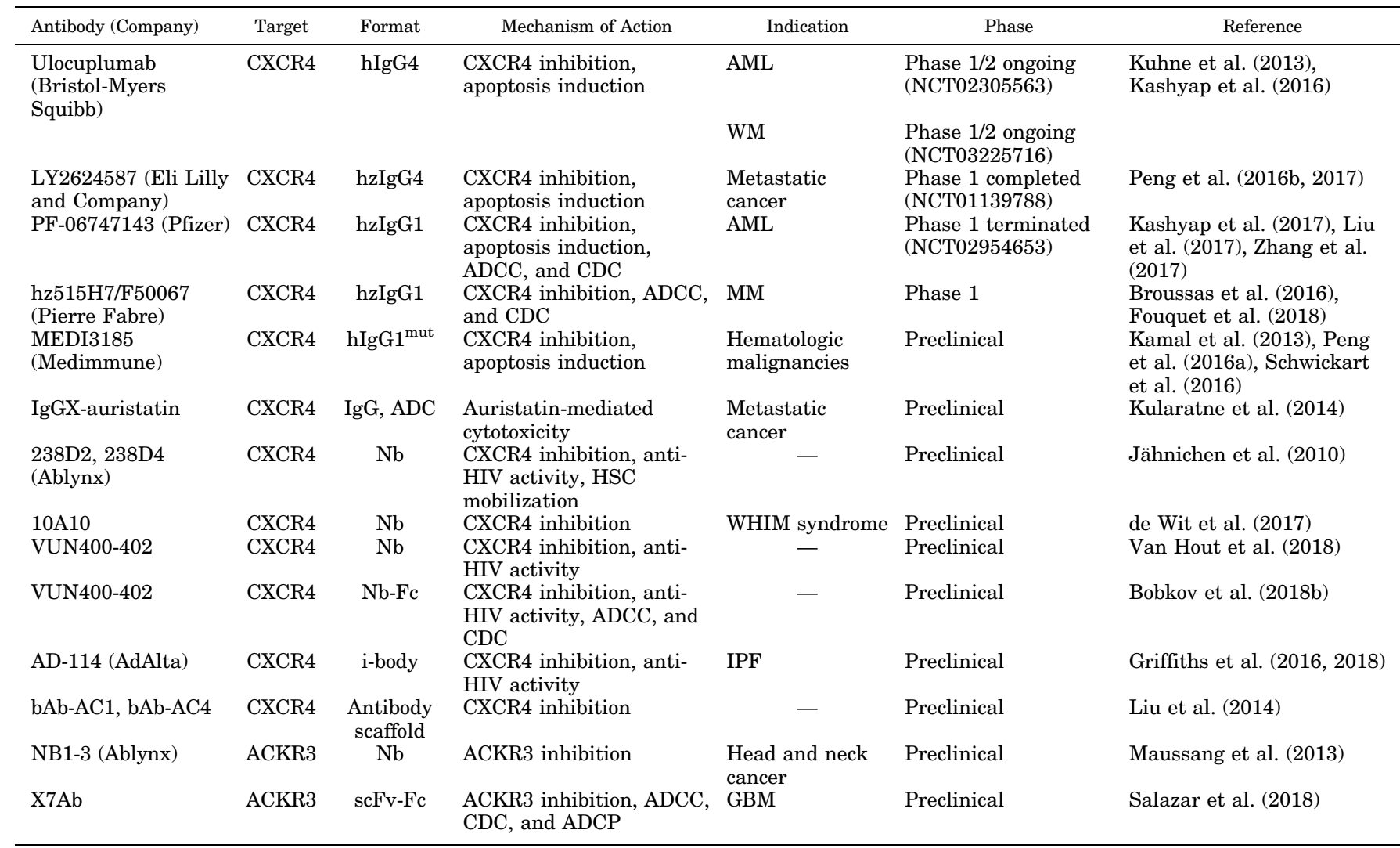

ADC, antibody-drug conjugate; ADCP, antibody-dependent cellular phagocytosis; AML, acute myeloid leukemia; GBM, glioblastoma; hIgG, human IgG; HSC,

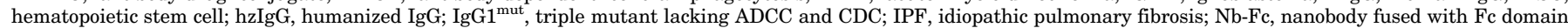

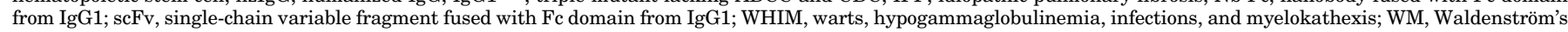
macroglobulinemia.

migration. The anticancer activity of this mAb is solely mediated by blocking CXCR4 function and inducing apoptosis (Kuhne et al., 2013; Kashyap et al., 2016). LY2624587 is another anti-CXCR4 IgG4 antibody with similar mode of action, which has also reached the clinical trial phase (Table 2) (Peng et al., 2016b). The combination of CXCR4 inhibition, induction of apoptosis, and ADCC and CDC effector functions is employed in an IgG1 from Pfizer, PF-06747143, and shows a strong effect in multiple hematologic tumor models (Table 2) (Kashyap et al., 2017; Liu et al., 2017; Zhang et al., 2017). Utilization of different antibody formats and Fc engineering strategies provides an attractive flexibility in pursuing specific therapeutic needs.

Small-molecule drugs often target orthosteric binding pockets, which are highly conserved among the family of GPCRs, especially for receptors sharing common ligands. Antibodies can overcome this off-target issue and provide better specificity by binding ECLs and the N-terminus, the regions of GPCRs representing the greatest diversity (Venkatakrishnan et al., 2013). Also, the overall druggability of chemokine receptors appears to be challenging for small-molecule competitive antagonists due to the extensive chemokine binding interface (Kufareva et al., 2017). In this context, it is worth noting that for the anti-CXCR4 antibody MEDI3185 the paratope and binding epitope have been described in detail. The interaction of the antibody is likely to be into a $\beta$-strand $/ \beta$-strand fashion between complementarity-determining region 3 (CDR3) of the heavy chain and the ECL2 of CXCR4, which explains the inhibitory activity of the antibody through steric hindrance with CXCL12 (Peng et al., 2016a). This binding mode appears to be different from those of small molecules and peptides and might be beneficial for inhibition of chemokine receptors.

Autoantibodies against CXCR4 have been reported in patients with systemic sclerosis (Weigold et al., 2018). While most autoantibodies directed at GPCRs were shown to have agonistic properties (Wallukat and Schimke, 2014; CabralMarques et al., 2018), the functionality and binding epitopes of the reported CXCR4 autoantibodies have not been described (Recke et al., 2018). In contrast, antagonistic properties would be advantageous in therapeutic antibodies to block receptor function involved in disease progression. Thus far, only antagonistic therapeutic antibodies have been developed for CXCR4 (Table 2). Binding epitopes of some of these antibodies and nanobodies, and related functional activities, will be further discussed in the paper.

To our knowledge, currently there are no reported therapeutic mAbs against ACKR3 in preclinical or clinical development. One group reported an application of ${ }^{89} \mathrm{Zr}-11 \mathrm{G} 8$, a radiolabeled murine IgG1, for positron emission tomography studies in xenograft mice but without any therapeutic effects described (Behnam Azad et al., 2016). This contrasts with a relatively broad panel of mAbs targeting CXCR4, as summarized in Table 2. Although it is beyond the scope of this review, it is worth mentioning that most of the generated 
ACKR3-targeting small-molecule compounds and peptides to date function as agonists (Wang et al., 2018). Functional inhibition of ACKR3 by nanobodies and an antibody-based fusion construct have been reported and will be discussed further. Overall, antibodies represent a promising new class of therapeutics with improved specificity and potency inhibiting chemokine receptors such as CXCR4 and ACKR3.

\section{Single-Domain Antibodies as Therapeutics and Tools in GPCR Research}

Although small molecules are mostly used to target GPCRs, their use has been accompanied with issues relating to selectivity, specificity, and potency (Hutchings et al., 2017; Sriram and Insel, 2018). Antibodies and antibody fragments are a good alternative to resolve some of these issues. A variety of different antibody formats was engineered in the past with each format having distinct advantages and disadvantages (Chames et al., 2009; Fernandes, 2018). Some of the more commonly used formats can be found in Fig. 1 .

One interesting type of antibody fragments used to target GPCRs is the nanobody. These fragments are derived from heavy chain-only antibodies, which are uniquely found in animals from the camelid family. Nanobodies are roughly 10 times smaller than conventional mAbs and have a more convex binding surface, which makes it easier to target cryptic epitopes that conventional mAbs cannot reach (De Genst et al., 2006; Muyldermans, 2013). GPCR-targeting nanobodies are more easily generated, even though conventional mAbs have been developed against GPCRs. To date, multiple publications show the potential of nanobodies as research tools and therapeutics for GPCRs.

Antibody Fragments as Tools in Crystallization Studies. In the past few years, GPCR crystal structures have proven to be essential tools in drug development. However, obtaining crystal structures is a challenging task due to multiple conformations of receptors (Manglik and Kobilka, 2014). To overcome this, nanobodies, and other antibody fragments, are used to stabilize distinct GPCR conformations in order to enable crystallization of these receptors by reducing the conformational heterogeneity. To obtain these conformation-stabilizing nanobodies, also referred to as confobodies, llamas or alpacas are immunized with purified receptors that are in complex with agonists or antagonists to stabilize the active or inactive conformation. Subsequent selections with the ligand-receptor complex are performed to obtain conformational stabilizers, which have been successfully used to crystallize GPCRs. By this means, active and/or inactive conformations of different receptors have been obtained. Targets thus far include the $\beta_{2}$ adrenergic receptor, $\mathrm{M}_{2}$ muscarinic acetylcholine receptor, $\mu$-opioid receptor, $\kappa$-opioid receptor, and the viral chemokine receptor US28 (Rasmussen et al., 2007, 2011; Kruse et al., 2013; Ring et al., 2013; Burg et al., 2015; Huang et al., 2015; Godar et al., 2018). The use of stabilizing nanobodies even makes it possible to crystallize GPCRs in complex with low-affinity ligands, what was previously only possible with high-affinity ligands (Ring et al., 2013). Next to crystallization, these nanobodies have also been used in drug discovery programs to obtain agonists for different receptors by stabilizing the active conformation (Chevillard et al., 2018; Pardon et al., 2018).
GPCR-Targeting Intrabodies. Small molecules modulate GPCRs by binding to the extracellular or the intracellular side of the receptor. In a similar manner, antibodies and their fragments can also target intracellular epitopes. However, their therapeutic value is limited due to their inability to cross the plasma membrane. Despite this, intracellular expression of these mAbs or fragments, which are referred to as intrabodies, overcomes this problem, making them interesting research tools for investigating GPCR signaling.

Modulation of GPCR signaling and receptor expression has been achieved by expressing $\beta_{2}$ adrenergic receptor-specific intrabodies (Staus et al., 2014). Besides modulating GPCR signaling, intrabodies can also be used as biosensors. For example, nanobodies used for the crystallization of GPCRs were fused to GFP and used for the visualization of spatiotemporal receptor trafficking and activation. For various GPCRs, intrabodies have provided greater insight into trafficking and signaling of these receptors, in particular from endosomes (Irannejad et al., 2013; Stoeber et al., 2018).

Next to receptor-specific intrabodies, more generic intrabodies can target GPCR-interaction partners. For example, intrabodies targeting $\beta$-arrestin can act as generic GPCR endocytosis inhibitors without affecting $\beta$-arrestin-mediated signaling (Ghosh et al., 2017). Another study generated an intrabody that targeted $\mathrm{G}_{\beta \gamma}$ and competed with the binding $\mathrm{G}_{\beta \gamma}$-interaction partners while having no effect on $\mathrm{G}_{\alpha q^{-}}$or $\mathrm{G}_{\alpha \mathrm{s}}$-mediated signaling (Gulati et al., 2018). In addition, a generic $\mathrm{Nb}$ biosensor was generated that bound the active form of $G_{\alpha \mathrm{s}}$ and was used to detect the activation of GPCRs in endosomes (Irannejad et al., 2013; Ismail et al., 2016).

In Vivo Imaging Tools. mAbs and antibody derivatives can also be used as in vivo imaging tools. Most commonly used labeling strategies involve the incorporation of radiolabels or fluorescent groups into mAbs (Freise and Wu, 2015). mAbs targeting CXCR4 or ACKR3 were used as in vivo imaging tools. In this case, antibodies were radiolabeled with ${ }^{89} \mathrm{Zr}$ and could detect GPCR expression in xenograft tumors in mice using positron emission tomography (Azad et al., 2016; Behnam Azad et al., 2016). To our knowledge, no GPCRtargeting nanobodies have been used thus far for in vivo imaging. However, numerous studies show that nanobodies in combination with different tracers can be used as imaging tools. This could be an interesting approach for in vivo imaging of GPCRs (Massa et al., 2016; Iezzi et al., 2018).

Nanobodies as Therapeutics. Conventional antibodies are well established as therapeutics, while nanobodies are emerging as potential therapeutic agents. As described previously, nanobodies are a good alternative to conventional mAbs for difficult targets including membrane bound receptors and enzymes. Nanobodies are also relatively low cost and high yielding in terms of manufacturing processes. They can also be administered via multiple routes (injection, nebulization, and oral and ocular administration), which makes them therapeutically interesting (Frenzel et al., 2013; Sheridan, 2017). To date, one nanobody, Caplacizumab, has obtained positive phase III results and was launched in Europe in October 2018 (Kaplon and Reichert, 2018). It targets the von Willebrand factor as a treatment against acquired thrombotic thrombocytopenic purpura.

Multiple studies describe nanobodies that modulate GPCRs, what show their potential as GPCR-targeting therapeutics. Other GPCR targets, besides CXCR4 and ACKR3, 
include CXCR2, ChemR23, mGlu2 receptor, and US28 (Bradley et al., 2015; Peyrassol et al., 2016; Scholler et al., 2017; Heukers et al., 2018).

Single-Domain Antibodies and Scaffolds Targeting CXCR4. Two nanobody candidates against CXCR4, 238D2 and 238D4 (Table 2), were shown to inhibit CXCL12 binding to CXCR4 with high affinity (Jähnichen et al., 2010). Despite binding two different epitopes of the extracellular part of CXCR4, the two nanobodies demonstrated full inhibition of CXCL12-mediated $\mathrm{G}_{\mathrm{i}}$ signaling in terms of both inositol phosphate accumulation and cAMP production inhibition. These nanobodies were also able to inhibit CXCL12-induced Jurkat cell migration. Linking the two nanobodies together (238D2-238D4) via a short peptide linker resulted in increased affinity and potency. The increased potency of such biparatopic nanobodies might be a result of simultaneous binding to two CXCR4 molecules in close proximity or within a dimer or higher-order oligomer. The biparatopic nanobodies, in contrast to their monovalent counterparts, exhibited inverseagonistic properties in inositol phosphate accumulation when tested with the CXCR4 constitutively active mutant N3.35A. Both monovalent and bivalent nanobodies could effectively inhibit CXCR4-mediated HIV entry in cells (Jähnichen et al., 2010). Just as the marketed CXCR4 antagonist AMD3100 (Cashen, 2009), the bivalent nanobody potently triggered the mobilization of both white blood cells and CD34+ stem cells in cynomolgus monkeys (Jähnichen et al., 2010).

Similarly, another nanobody called 10A10 (Table 2) was generated (de Wit et al., 2017), targeting wild-type CXCR4 as well as warts, hypogammaglobulinemia, infections, and myelokathexis syndrome variants CXCR4-R334X and CXCR4S338X with a truncated C-terminal tail. This nanobody was able to fully displace CXCL12 on all CXCR4 constructs, and similar to the nanobodies 238D2 and 238D4, showed improved affinity when generated as a bivalent construct (10A1010A10). The monovalent and bivalent formats of 10A10 were able to inhibit CXCL12-mediated CXCR4 downregulation of cAMP production, extracellular signal-regulated kinase 1/2 phosphorylation, and inositol phosphate accumulation. The bivalent 10A10 could also inhibit CXCR4 calcium mobilization in K652 myeloid leukemic cells. As for the warts, hypogammaglobulinemia, infections, and myelokathexis syndrome linked to human papillomavirus-associated malignancies (Beaussant Cohen et al., 2012), 10A10-10A10 was tested in a human papillomavirus-related assay and partially inhibited human papillomavirus-driven migration of human keratinocytes, which is mediated by the CXCL12CXCR4 axis.

Using an alternative approach, we have created bivalent nanobodies against CXCR4 by fusing them with an Fc domain from human IgG1. Initially developed monovalent nanobodies VUN400-402 (Table 2), which bind distinct but overlapping epitopes, demonstrated divergent activity in inhibition of HIV entry and CXCR4-related functions (Van Hout et al., 2018). VUN402 showed selective activity toward inhibiting a broad range of HIV strains with only poor blockage of CXCL12 binding, chemotaxis, and CXCL12-induced cell morphology change. This shows the potential of nanobodies as selective HIV-blocking agents. In a follow-up study, these three nanobodies were formatted as bivalent nanobodies fused with an Fc fragment (Nb-Fc), VUN400-Fc, VUN401-Fc, and VUN402-Fc. The generated constructs demonstrated significantly higher affinities to CXCR4, and also increased potencies toward inhibiting CXCL12 binding, signaling, cell morphology change, and HIV entry. Additionally, Fc-mediated induction of ADCC and CDC was demonstrated with a human leukemia cell line CCRF-CEM (Bobkov et al., 2018b). Nb-Fc constructs could potentially show reduced blood clearance, in comparison with nanobodies, with their increased size and access to the antibody recycling pathway through the neonatal Fc receptor (FcRn) via the Fc domain. This approach entails a new class of molecules targeting GPCRs with the combined favorable properties of nanobodies and the functional utility of conventional antibodies.

Immunoglobulin new antigen receptors are another class of single-domain antibodies found in the immune system of sharks (Fig. 1). Their antigen-binding domains are represented by small variable fragments of immunoglobulin new antigen receptors, which have similar binding properties as nanobodies and were selected for specific diagnostic and therapeutic purposes against different targets, such as AMA-1, Ebolavirus nucleoprotein, tumor necrosis factor $\alpha$, and vascular endothelial growth factor (Nuttall et al., 2004; Goodchild et al., 2011; Camacho-Villegas et al., 2013, 2018). The structural similarity between the variable fragment of immunoglobulin new antigen receptor and I-set family of human immunoglobulin domains, for example, neural cell adhesion molecule 1, has been reported previously (Streltsov et al., 2004). The usage of neural cell adhesion molecules as scaffolds by incorporating binding loops, mimicking CDRs, allows construction of fully human analogs of variable fragments of immunoglobulin new antigen receptors, designated as i-bodies (Griffiths et al., 2016). Several CXCR4 antagonistic i-bodies have been also reported, which bind deep in the ligand binding pocket of the receptor via the elongated CDR3 loop, and showed inhibition of cell migration and HIV infection but not mobilization of hematopoietic stem cells. Of interest, the i-body AD-114 (Table 2) demonstrated an antifibrotic effect and diminished the level of lung injury in an in vivo murine model of pulmonary fibrosis (Griffiths et al., 2018). This antiCXCR4 i-body was proposed as a potential candidate for the treatment of idiopathic pulmonary fibrosis.

Another scaffold engineering approach involves grafting a modified CXCR4-targeting peptide CVX15 into a bovine antibody with ultralong CDRH3 (Liu et al., 2014). The resulting antibody scaffolds, bAb-AC1 and bAb-AC4 (Table 2), with the peptide grafted into $\mathrm{CDRH} 3$ or $\mathrm{CDRH} 2$, respectively, showed specific binding to CXCR4 expressing cells with nanomolar affinities, inhibition of CXCL12-mediated signaling, and cell migration. This approach illustrates an application of antibodies as scaffolds for peptides targeting GPCRs, broadening their therapeutic prospects.

Nanobodies and Other Fragments Targeting ACKR3. Three generated nanobodies against ACKR3 (NB1, NB2, and NB3) exhibited CXCL12 displacement properties; while NB2 and NB3 fully inhibited CXCL12 binding to ACKR3, NB1 only showed partial inhibition despite having good affinity (Maussang et al., 2013). Consistently, NB2 and NB3 could completely inhibit CXCL12-induced $\beta$-arrestin- 2 recruitment with submicromolar and nanomolar potencies, respectively, whereas NB1 was unable to inhibit recruitment even at high concentrations. Comparable to the CXCR4 nanobodies, the ACKR3-targeting nanobodies were also formatted as bivalent NB2-NB2 and biparatopic NB1-NB3 constructs. For in vivo 
purposes, both constructs were genetically linked to a nanobody targeting albumin for an increased blood half-life. As expected, these new constructs demonstrated increased affinity and potency toward ACKR3. In the head and neck cancer cell line 22A, which highly expresses ACKR3, the NB1-NB3 nanobody did not influence cell-cycle progression but inhibited the secretion of angiogenic factor CXCL1. In a xenograft model system using 22A cells, the biparatopic NB1-NB3 effectively reduced tumor growth and decreased CD31 marker expression in tumors, while the bivalent NB2-NB2 did not. The use of ACKR3-targeting nanobodies demonstrated that ACKR3 plays a role in angiogenesis.

Fusion of single-chain variable fragments recognizing human ACKR3 with an Fc portion of IgG1 resulted in the generation of the antibody derivative X7Ab (Table 2) that inhibited CXCL12 signaling (Salazar et al., 2018). X7Ab was able to kill ACKR3-expressing glioblastoma cells via Fcmediated ADCC, CDC, and antibody-dependent cellular phagocytosis, and in combination with temozolomide significantly reduced tumor growth and improved overall survival in a mouse glioblastoma model.

\section{Structural Analysis of Antibodies/Nanobodies Binding to CXCR4}

Antibodies are modular proteins that consist of four polypeptide chains - two light and two heavy chains. Each light and heavy chain is linked to each other through disulphide bonds, forming two identical Fabs. Each Fab consists of two variable domains (variable heavy[VH], and variable light [VL]), and two constant domains (constant heavy 1, [CH1], and constant light, [CL], in the heavy and light chains, respectively). The two variable domains (VH and VL) contain an antigen-binding site, also called a paratope. Other domains of the heavy chains (constant heavy 2 [CH2] and constant heavy 3 [CH3])form the Fc region.

A paratope results from the specific folding of six hypervariable loops of the variable domains known as complementarity determining regions, three in the light chain (CDRL1, CDRL2 and CDRL3) and three in the heavy chain (CDRH1, CDRH2, and CDRH3) (Putnam et al., 1979; Sela-Culang et al., 2013). The six CDR loops mediate antigen recognition, while the constant domains in the Fc region are responsible for inducing effector functions of an antibody. Despite the high structural similarity between antibodies, their binding capabilities are enormously diverse (Sela-Culang et al., 2013).

Nanobodies are derived from a single variable domain of heavy chain-only antibodies found in llamas and camels, and therefore their paratope is composed only of three CDR loops, CDRH1-3. Interestingly, the CDRH3 of nanobodies is often elongated, favoring binding of conformational epitopes on a target molecule hidden from conventional antibodies (Mujić-Delić et al., 2014).

Antigen-antibody recognition involves a series of noncovalent interactions between an antibody paratope and a binding site on an antigen, or an epitope. The exact composition of the paratope is antibody dependent, and therefore represents a challenge for the study of the antibody-antigen interface. Identification of paratopes is often done through the identification of amino acid residues within CDRs, which are the most variable regions between antibodies. However, not all residues within the CDRs are involved in antigen binding; only a small percentage according to the previous analyses (Padlan, 1994; Ofran et al., 2008). Nevertheless, the CDR residues not directly involved in antigen binding play a key role in forming a favorable conformation of the CDRs (SelaCulang et al., 2013). The specific conformation of the different loops containing the paratope residues is crucial for recognizing the antigen with high specificity and affinity, as proven by CDR-derived linear peptides, which bind their antigens with considerably lower affinities (Saragovi et al., 1991; Polonelli et al., 2008).

CDR3 is considered to be the most important region for antigen binding, but CDR2 is longer on average and has been proven to form the same number of interactions with the antigen (Kunik and Ofran, 2013). Furthermore, CDR2 is proven to be the most solvent exposed of all loops (Hattori et al., 2008), which might relate to its longer length. Also, in terms of energetic contribution of binding, CDR3 provides on average the highest contributions, but there are cases where other CDRs, including CDR2, contribute the most to the binding energy (Burkovitz et al., 2013; Kunik and Ofran, 2013; Sela-Culang et al., 2013). This fact emphasizes the high variability on the antigen recognition of each antibody, and the need for specific analysis to better understand the antibody-antigen interface and to attempt to pharmacologically enhance or disrupt it.

Mutation of residues in the binding pocket of small molecules and peptides, such as D97 ${ }^{2.63}$, Y116 ${ }^{3.32}$, D171 $1^{4.60}$, $\mathrm{Q} 200^{5.39}$, or E288 ${ }^{7.39}$ in CXCR4, does not affect the binding of antibodies and nanobodies (Fig. 3). CXCR4 residues are annotated with the UniProt numbering (https://www.uniprot. org/), followed by the Ballesteros-Weinstein annotation, when applicable (in the Ballesteros-Weinstein annotation the first number before the dot indicates the transmembrane helix and the value after the dot indicates the relative position of the residue in the helix with respect to the most conserved residue, randomly designated as 50 ). Indeed, several studies have probed the CXCR4 epitope using mutagenesis, and concluded that CXCR4 antibodies and nanobodies recognize different domains within the extracellular region of the receptor, including the $\mathrm{N}$-terminus and the three ECLs (Figs. 3 and 4). This explains why often small molecules are not able to displace antibodies or nanobodies. To illustrate, AMD3100 does not affect the binding of MEDI3185 to CXCR4 (Peng et al., 2016a).

As shown in Fig. 4, most antibody and nanobody epitopes involve multiple residues in the CXCR4 ECL2, including, e.g., E179, D181, and D187. This indicates that the most significant interactions between CXCR4 and antibodies and nanobodies might be electrostatic in nature. However, several studies report nonsignificant effects from single-point mutations in ECL2, while the impact of large substitutions or multiple simultaneous mutations show marked impairment on their binding (Xu et al., 2007; Peng et al., 2016a). These observations indicate that the epitope of these antibodies may be dispersed throughout ECL2 (Fig. 4A). The same phenomena are observed in mutations of the $\mathrm{N}$-terminus, where large deletions significantly affect the binding of CXCR4 antibodies 12G5 and 6H8 (Brelot et al., 2000).

Nanobodies are believed to be able to recognize more buried epitopes (e.g., binding pockets) due to their smaller size and molecular structure. The antibody-like scaffolds called i-bodies, AM3-114, AM3-523, and AM4-272, have been 


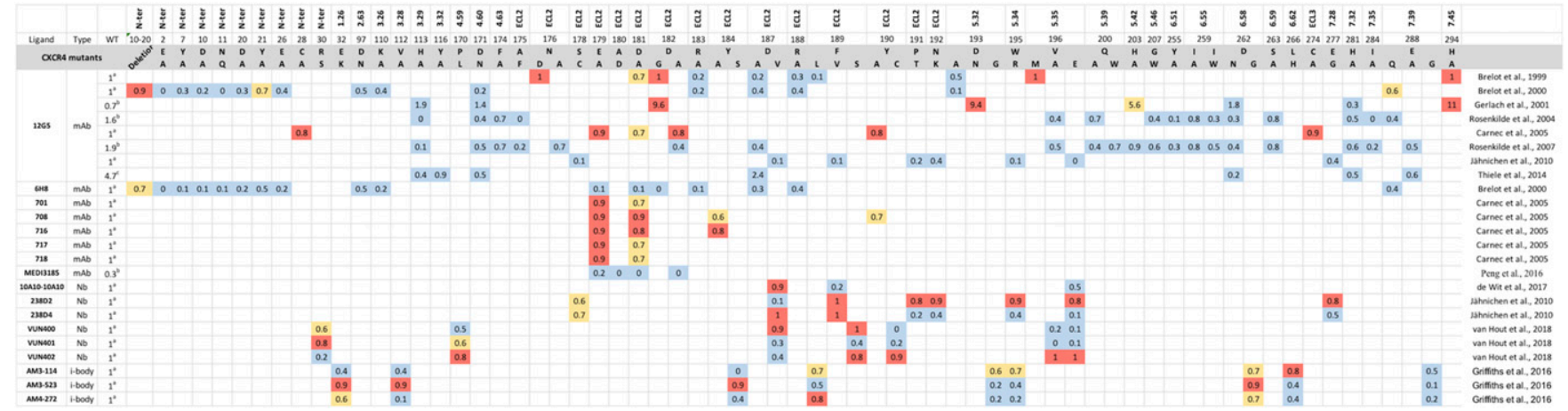

Fig. 3. Differences between the reactivity, $K_{\mathrm{d}}$, or $\mathrm{IC}_{50}$ values of wild-type (WT) and mutant (WT value - mutant value/WT value) reported for $17 \mathrm{CXCR} 4$ antibodies, nanobodies, and antibody-like scaffolds extracted from the literature (Brelot et al., 1999, 2000; Gerlach et al., 2001; Rosenkilde et al., 2004, 2007; Carnec et al., 2005; Jähnichen et al., 2010; Thiele et al., 2014; Griffiths et al., 2016; Peng et al., 2016a; de Wit et al., 2017; Van Hout et al., 2018). The effects are colored for easier interpretation as follows: blue for the less significant effect (reactivity difference $0-0.5$, $K_{\mathrm{d}} / \mathrm{IC}_{50}$ difference 0 - to 3 -fold units), yellow for an intermediate effect (reactivity difference $0.5-0.7, K_{\mathrm{d}} / \mathrm{IC}_{50}$ difference 3 - to 8-fold units), and red for the most significant effects (reactivity difference $0.7-1, K_{\mathrm{d}} / \mathrm{IC}_{50}$ difference $>8$-fold units).

reported to bind to more buried amino acids within CXCR4 (Griffiths et al., 2016), including V112 $2^{3.28}$ and D262 $2^{6.58}$, which are rather close to the extracellular surface of the receptor. Other nanobodies, including 238D2, 238D4, VUN400, VUN401, and VUN402, show unique but overlapping epitopes mostly involving the N-terminus and ECL2 of CXCR4 (Jähnichen et al., 2010; Van Hout et al., 2018), similar to mAbs (Fig. 4B).

Despite the overall common epitope, each antibody and nanobody has a specific pattern of binding, which often correlates with its unique mode of action. To illustrate this, antibodies and nanobodies binding to different epitopes are able to differentially inhibit CXCL12, block the entrance of different HIV strains, or inhibit CXCL12-induced signaling (Carnec et al., 2005; Jähnichen et al., 2010; Peng et al., 2016a; de Wit et al., 2017; Van Hout et al., 2018). However, the binding mode of these antibodies and nanobodies and their molecular mechanism of action are still poorly understood. Protein-protein interactions, such as the antigen-antibody interface, are challenging to predict and require experimental identification of residues involved in the interaction from both

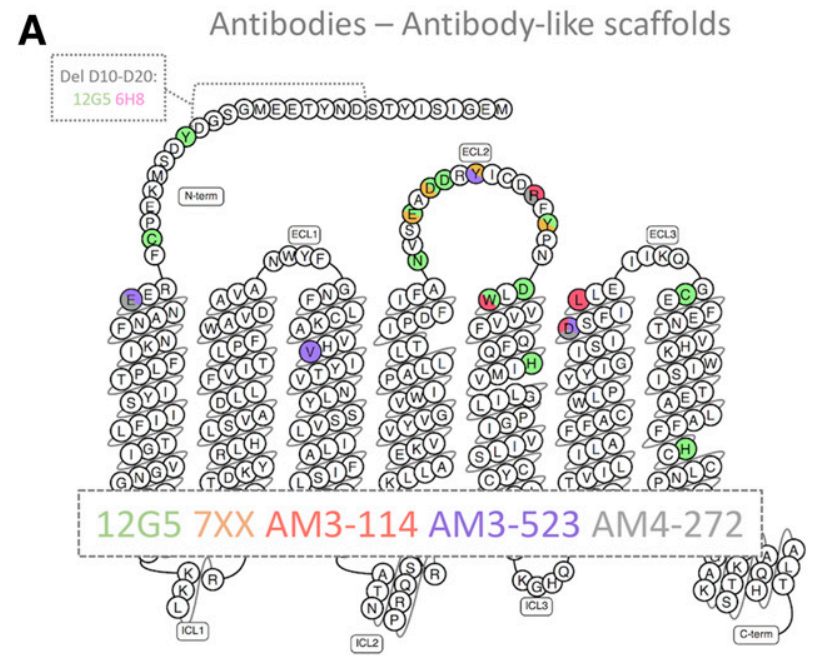

proteins. As described in this section, several studies aimed to identify the epitope on the receptor side, while only one study has focused on the identification of the CXCR4-targeting antibody paratope (Peng et al., 2016a). In these studies they selected the residues near the apex of each loop for mutagenesis, which are more likely to be solvent exposed and therefore antigen accessible. CDR3 was found to be the most critical for binding, with smaller contributions from CDR1. With this knowledge, these authors were able to predict the mode of interaction between CXCR4 and MEDI3185, enabling designing new specific therapeutics targeting CXCR4.

\section{Conclusions}

CXCR4 and ACKR3 are two therapeutic targets with great potential in view of their involvement in tumorigenesis and autoimmune disorders. Their role in disease progression and expression pattern, and the fact that they both bind CXCL12, creates an opportunity to consider them for dual targeting, which might be superior in treatment of cancer. Several

B Nanobodies

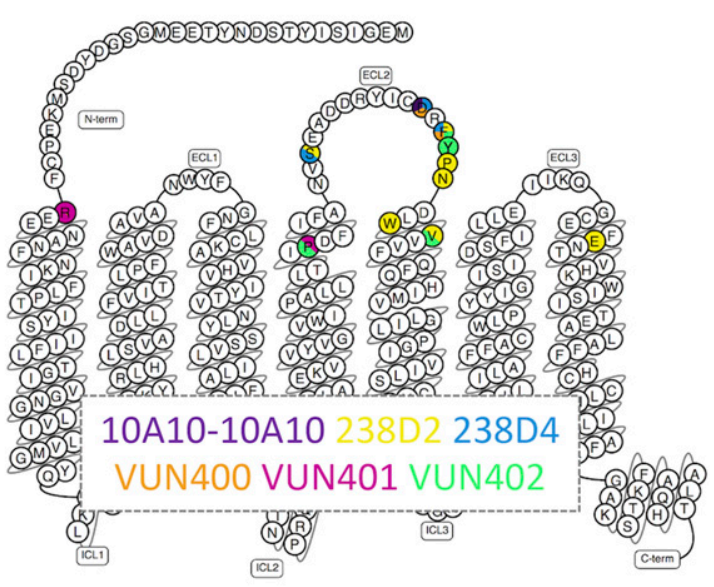

Fig. 4. CXCR4 snake plot representations with the most relevant residues involved on the binding of each antibody and antibody-like scaffold (A) or nanobody (B), as indicated in Fig. 3. Snake plots are based on GPCRdb representations (Pándy-Szekeres et al., 2018). 
anti-CXCR4 mAbs are in clinical development with many more antibodies, nanobodies, and other fragments in preclinical stage. Also, some antibodies and nanobodies blocking ACKR3 function have been developed. Nevertheless, there are still no antibodies approved against CXCR4 or ACKR3, representing a clear niche for development of novel CXCR4and ACKR3-targeting biologics. Nanobodies and nanobodybased molecules are an interesting alternative to mAbs because of their unique properties advancing GPCR targeting.

We described how antibodies and nanobodies are versatile and promising tools for in vitro GPCR studies, as well as for clinical applications. It is important to decipher the structural and molecular mechanisms by which they recognize and bind their antigens. Such understanding will be valuable for better prediction of binding epitopes but also for the engineering of new antibodies with desired binding properties.

\section{Acknowledgments}

This mini review is part of the mini review series "From insight to modulation of CXCR4 and ACKR3 (CXCR7) function." We thank all of our colleagues from the ONCORNET Consortium (www.oncornet.eu) for fruitful scientific discussions.

\section{Authorship Contributions}

Wrote or contributed to the writing of the manuscript: Bobkov, Arimont, Zarca, De Groof, van der Woning, de Haard, Smit.

\section{References}

Azad BB, Chatterjee S, Lesniak WG, Lisok A, Pullambhatla M, Bhujwalla ZM, Pomper MG, and Nimmagadda S (2016) A fully human CXCR4 antibody demonstrates diagnostic utility and therapeutic efficacy in solid tumor xenografts. Oncotarget 7:12344-12358.

Baribaud F, Edwards TG, Sharron M, Brelot A, Heveker N, Price K, Mortari F, Alizon M, Tsang M, and Doms RW (2001) Antigenically distinct conformations of CXCR4. J Virol 75:8957-8967.

Beaussant Cohen S, Fenneteau O, Plouvier E, Rohrlich PS, Daltroff G, Plantier I, Dupuy A, Kerob D, Beaupain B, Bordigoni P, et al. (2012) Description and outcome of a cohort of 8 patients with WHIM syndrome from the French Severe Chronic Neutropenia Registry. Orphanet J Rare Dis 7:71.

Beck A, Goetsch L, Dumontet C, and Corvaïa N (2017) Strategies and challenges for the next generation of antibody-drug conjugates. Nat Rev Drug Discov 16:315-337.

Beck A and Reichert JM (2012) Marketing approval of mogamulizumab: a triumph for glyco-engineering. MAbs 4:419-425.

Behnam Azad B, Lisok A, Chatterjee S, Poirier JT, Pullambhatla M, Luker GD, Pomper MG, and Nimmagadda S (2016) Targeted imaging of the atypical chemokine receptor 3 (ACKR3/CXCR7) in human cancer xenografts. J Nucl Med 57: 981-988.

Berahovich RD, Penfold ME, and Schall TJ (2010) Nonspecific CXCR7 antibodies. Immunol Lett 133:112-114

Bobkov V, van der Woning B, and de Haard H (2018a) Display technologies for generation of Ig single variable domains. Methods Mol Biol 1827:129-144.

Bobkov V, Zarca AM, Van Hout A, Arimont M, Doijen J, Bialkowska M, Toffoli E, Klarenbeek A, van der Woning B, van der Vliet HJ, et al. (2018b) Nanobody-Fc constructs targeting chemokine receptor CXCR4 potently inhibit signaling and CXCR4-mediated HIV-entry and induce antibody effector functions. Biochem Pharmacol 158:413-424.

Bodei S, Arrighi N, Spano P, and Sigala S (2009) Should we be cautious on the use of commercially available antibodies to dopamine receptors? Naunyn Schmiedebergs Arch Pharmacol 379:413-415.

Boder ET and Wittrup KD (1997) Yeast surface display for screening combinatorial polypeptide libraries. Nat Biotechnol 15:553-557.

Bradley ME, Dombrecht B, Manini J, Willis J, Vlerick D, De Taeye S, Van den Heede K, Roobrouck A, Grot E, Kent TC, et al. (2015) Potent and efficacious inhibition of CXCR2 signaling by biparatopic nanobodies combining two distinct modes of action. Mol Pharmacol 87:251-262.

Brave M, Farrell A, Ching Lin S, Ocheltree T, Pope Miksinski S, Lee SL, Saber H, Fourie J, Tornoe C, Booth B, et al. (2010) FDA review summary: mozobil in combination with granulocyte colony-stimulating factor to mobilize hematopoietic stem cells to the peripheral blood for collection and subsequent autologous transplantation. Oncology 78:282-288.

Brelot A, Heveker N, Adema K, Hosie MJ, Willett B, and Alizon M (1999) Effect of mutations in the second extracellular loop of CXCR4 on its utilization by human and feline immunodeficiency viruses. $J$ Virol 73:2576-2586.

Brelot A, Heveker N, Montes M, and Alizon M (2000) Identification of residues of CXCR4 critical for human immunodeficiency virus coreceptor and chemokine receptor activities. J Biol Chem 275:23736-23744.

Broussas M, Boute N, Akla B, Berger S, Beau-Larvor C, Champion T, Robert A, Beck A, Haeuw JF, Goetsch L, et al. (2016) A new anti-CXCR4 antibody that blocks the CXCR4/SDF-1 axis and mobilizes effector cells. Mol Cancer Ther 15:1890-1899.
Burg JS, Ingram JR, Venkatakrishnan AJ, Jude KM, Dukkipati A, Feinberg EN, Angelini A, Waghray D, Dror RO, Ploegh HL, et al. (2015) Structural biology. Structural basis for chemokine recognition and activation of a viral G proteincoupled receptor. Science 347:1113-1117.

Burkovitz A, Leiderman O, Sela-Culang I, Byk G, and Ofran Y (2013) Computational identification of antigen-binding antibody fragments. J Immunol 190:2327-2334.

Burns JM, Summers BC, Wang Y, Melikian A, Berahovich R, Miao Z, Penfold ME, Sunshine MJ, Littman DR, Kuo CJ, et al. (2006) A novel chemokine receptor for SDF-1 and I-TAC involved in cell survival, cell adhesion, and tumor development. J Exp Med 203:2201-2213.

Cabral-Marques O, Marques A, Giil LM, De Vito R, Rademacher J, Günther J, Lange T, Humrich JY, Klapa S, Schinke S, et al. (2018) GPCR-specific autoantibody signatures are associated with physiological and pathological immune homeostasis. Nat Commun 9:5224.

Camacho-Villegas T, Mata-Gonzalez T, Paniagua-Solis J, Sanchez E, and Licea A (2013) Human TNF cytokine neutralization with a vNAR from Heterodontus francisci shark: a potential therapeutic use. MAbs 5:80-85.

Camacho-Villegas TA, Mata-González MT, García-Ubbelohd W, Núñez-García L, Elosua C, Paniagua-Solis JF, and Licea-Navarro AF (2018) Intraocular penetration of a vNAR: in vivo and in vitro VEGF ${ }_{165}$ neutralization. Mar Drugs 16:E113.

Carnec X, Quan L, Olson WC, Hazan U, and Dragic T (2005) Anti-CXCR4 monoclonal antibodies recognizing overlapping epitopes differ significantly in their ability to inhibit entry of human immunodeficiency virus type 1. J Virol 79:1930-1933.

Cashen AF (2009) Plerixafor hydrochloride: a novel agent for the mobilization of peripheral blood stem cells. Drugs Today (Barc) 45:497-505

Chames P, Van Regenmortel M, Weiss E, and Baty D (2009) Therapeutic antibodies: successes, limitations and hopes for the future. Br J Pharmacol 157:220-233.

Chevillard F, Rimmer H, Betti C, Pardon E, Ballet S, van Hilten N, Steyaert J, Diederich WE, and Kolb P (2018) Binding-site compatible fragment growing applied to the design of $\beta_{2}$-adrenergic receptor ligands. J Med Chem 61:1118-1129. D'Alterio C, Nasti G, Polimeno M, Ottaiano A, Conson M, Circelli L, Botti G, Scognamiglio G, Santagata S, De Divitiis C, et al. (2016) CXCR4-CXCL12-CXCR7, TLR2-TLR4, and PD-1/PD-L1 in colorectal cancer liver metastases from neoadjuvant-treated patients. OncoImmunology 5:e1254313.

De Clercq E (2003) The bicyclam AMD3100 story. Nat Rev Drug Discov 2:581-587.

De Genst E, Silence K, Decanniere K, Conrath K, Loris R, Kinne J, Muyldermans S, and Wyns L (2006) Molecular basis for the preferential cleft recognition by dromedary heavy-chain antibodies. Proc Natl Acad Sci USA 103:4586-4591.

de Haard HJ, van Neer N, Reurs A, Hufton SE, Roovers RC, Henderikx P, de Bruïne AP, Arends JW, and Hoogenboom HR (1999) A large non-immunized human Fab fragment phage library that permits rapid isolation and kinetic analysis of high affinity antibodies. $J$ Biol Chem 274:18218-18230.

de Wit RH, Heukers R, Brink HJ, Arsova A, Maussang D, Cutolo P, Strubbe B, Vischer HF, Bachelerie F, and Smit MJ (2017) CXCR4-specific nanobodies as potential therapeutics for WHIM syndrome. $J$ Pharmacol Exp Ther 363:35-44.

Dolgin E (2018) First GPCR-directed antibody passes approval milestone. Nat Rev Drug Discov 17:457-459.

Fernandes JC (2018) Therapeutic application of antibody fragments in autoimmune diseases: current state and prospects. Drug Discov Today 23:1996-2002.

Fouquet G, Guidez S, Richez V, Stoppa AM, Le Tourneau C, Macro M, Gruchet C, Bobin A, Moya N, Syshenko T, et al. (2018) Phase I dose-escalation study of F50067, a humanized anti-CXCR4 monoclonal antibody alone and in combination with lenalidomide and low-dose dexamethasone, in relapsed or refractory multiple myeloma. Oncotarget 9:23890-23899.

Freise AC and $\mathrm{Wu} \mathrm{AM}$ (2015) In vivo imaging with antibodies and engineered fragments. Mol Immunol 67 (2 Pt A):142-152.

Frenzel A, Hust M, and Schirrmann T (2013) Expression of recombinant antibodies. Front Immunol 4:217.

Gerlach LO, Skerlj RT, Bridger GJ, and Schwartz TW (2001) Molecular interactions of cyclam and bicyclam non-peptide antagonists with the CXCR4 chemokine receptor. J Biol Chem 276:14153-14160.

Ghosh E, Srivastava A, Baidya M, Kumari P, Dwivedi H, Nidhi K, Ranjan R, Dogra S, Koide A, Yadav PN, et al. (2017) A synthetic intrabody-based selective and generic inhibitor of GPCR endocytosis. Nat Nanotechnol 12:1190-1198.

Godar M, de Haard H, Blanchetot C, and Rasser J (2018) Therapeutic bispecific antibody formats: a patent applications review (1994-2017). Expert Opin Ther Pat 28:251-276.

Goodchild SA, Dooley H, Schoepp RJ, Flajnik M, and Lonsdale SG (2011) Isolation and characterisation of Ebolavirus-specific recombinant antibody fragments from murine and shark immune libraries. Mol Immunol 48:2027-2037.

Griffiths K, Dolezal O, Cao B, Nilsson SK, See HB, Pfleger KD, Roche M, Gorry PR, Pow A, Viduka K, et al. (2016) i-Bodies, human single domain antibodies that antagonize chemokine receptor CXCR4. J Biol Chem 291:12641-12657.

Griffiths K, Habiel DM, Jaffar J, Binder U, Darby WG, Hosking CG, Skerra A Westall GP, Hogaboam CM, and Foley M (2018) Anti-fibrotic effects of CXCR4 targeting i-body $\mathrm{AD}-114$ in preclinical models of pulmonary fibrosis. Sci Rep 8: 3212

Gulati S, Jin H, Masuho I, Orban T, Cai Y, Pardon E, Martemyanov KA, Kiser PD, Stewart PL, Ford CP, et al. (2018) Targeting G protein-coupled receptor signaling at the G protein level with a selective nanobody inhibitor. Nat Commun 9:1996.

Guo JC, Li J, Zhou L, Yang JY, Zhang ZG, Liang ZY, Zhou WX, You L, Zhang TP, and Zhao YP (2016) CXCL12-CXCR7 axis contributes to the invasive phenotype of pancreatic cancer. Oncotarget 7:62006-62018

Hanes J, Schaffitzel C, Knappik A, and Plückthun A (2000) Picomolar affinity antibodies from a fully synthetic naive library selected and evolved by ribosome display. Nat Biotechnol 18:1287-1292.

Hattori T, Umetsu M, Nakanishi T, Tsumoto K, Ohara S, Abe H, Naito M, Asano R Adschiri T, and Kumagai I (2008) Grafting of material-binding function into antibodies Functionalization by peptide grafting. Biochem Biophys Res Commun 365:751-757. 
Heukers R, Fan TS, de Wit RH, van Senten JR, De Groof TWM, Bebelman MP, Lagerweij T, Vieira J, de Munnik SM, Smits-de Vries L, et al. (2018) The constitutive activity of the virally encoded chemokine receptor US28 accelerates glioblastoma growth. Oncogene 37:4110-4121.

Hollenstein K, de Graaf C, Bortolato A, Wang MW, Marshall FH, and Stevens RC (2014) Insights into the structure of class B GPCRs. Trends Pharmacol Sci 35: $12-22$.

Huang W, Manglik A, Venkatakrishnan AJ, Laeremans T, Feinberg EN, Sanborn AL, Kato HE, Livingston KE, Thorsen TS, Kling RC, et al. (2015) Structural insights into $\mu$-opioid receptor activation. Nature 524:315-321.

Hutchings CJ, Koglin M, and Marshall FH (2010) Therapeutic antibodies directed at G protein-coupled receptors. MAbs 2:594-606.

Hutchings CJ, Koglin M, Olson WC, and Marshall FH (2017) Opportunities for therapeutic antibodies directed at G-protein-coupled receptors [published correction appears in Nat Rev Drug Discov (2017) 16:661]. Nat Rev Drug Discov 16: 787-810.

Iezzi ME, Policastro L, Werbajh S, Podhajcer O, and Canziani GA (2018) Singledomain antibodies and the promise of modular targeting in cancer imaging and treatment. Front Immunol 9:273.

Irannejad R, Tomshine JC, Tomshine JR, Chevalier M, Mahoney JP, Steyaert J, Rasmussen SG, Sunahara RK, El-Samad H, Huang B, et al. (2013) Conformational biosensors reveal GPCR signalling from endosomes. Nature 495:534-538.

Ismail S, Gherardi MJ, Froese A, Zanoun M, Gigoux V, Clerc P, Gaits-Iacovoni F, Steyaert J, Nikolaev VO, and Fourmy D (2016) Internalized receptor for glucosedependent insulinotropic peptide stimulates adenylyl cyclase on early endosomes. Biochem Pharmacol 120:33-45.

Ito A, Ishida T, Yano H, Inagaki A, Suzuki S, Sato F, Takino H, Mori F, Ri M, Kusumoto S, et al. (2009) Defucosylated anti-CCR4 monoclonal antibody exercises potent ADCC-mediated antitumor effect in the novel tumor-bearing humanized NOD/ Shi-scid, IL-2R $\gamma^{\text {null }}$ mouse model. Cancer Immunol Immunother 58:1195-1206.

Jähnichen S, Blanchetot C, Maussang D, Gonzalez-Pajuelo M, Chow KY, Bosch L, De Vrieze S, Serruys B, Ulrichts H, Vandevelde W, et al. (2010) CXCR4 nanobodies (VHH-based single variable domains) potently inhibit chemotaxis and HIV-1 replication and mobilize stem cells. Proc Natl Acad Sci USA 107:20565-20570.

Kamal A, Wang Y, Steiner P, Mazzola A-M, Wetzel L, Passino M, McDermott B, Huang K, Bedian V, and Greenberg N (2013) Abstract 5462: MEDI3185, a potent anti-CXCR4 antibody, inhibits tumor cell migration, signaling and tumor growth in preclinical models. Cancer Res 73 (8 Suppl):5462.

Kaplon H and Reichert JM (2018) Antibodies to watch in 2018. MAbs 10:183-203.

Kashyap MK, Amaya-Chanaga CI, Kumar D, Simmons B, Huser N, Gu Y, Hallin M, Lindquist K, Yafawi R, Choi MY, et al. (2017) Targeting the CXCR4 pathway using a novel anti-CXCR4 IgG1 antibody (PF-06747143) in chronic lymphocytic leukemia. J Hematol Oncol 10:112.

Kashyap MK, Kumar D, Jones H, Amaya-Chanaga CI, Choi MY, Melo-Cardenas J, Ale-Ali A, Kuhne MR, Sabbatini P, Cohen LJ, et al. (2016) Ulocuplumab (BMS936564/MDX1338): a fully human anti-CXCR4 antibody induces cell death in chronic lymphocytic leukemia mediated through a reactive oxygen speciesdependent pathway. Oncotarget 7:2809-2822.

Kirkpatrick P (2009) Specificity concerns with antibodies for receptor mapping. Nat Rev Drug Discov 8:278.

Köhler G and Milstein C (1975) Continuous cultures of fused cells secreting antibody of predefined specificity. Nature 256:495-497.

Kruse AC, Ring AM, Manglik A, Hu J, Hu K, Eitel K, Hübner H, Pardon E, Valant C, Sexton PM, et al. (2013) Activation and allosteric modulation of a muscarinic acetylcholine receptor. Nature 504:101-106.

Kufareva I, Gustavsson M, Zheng Y, Stephens BS, and Handel TM (2017) What do structures tell us about chemokine receptor function and antagonism? Annu Rev Biophys 46:175-198.

Kuhne MR, Mulvey T, Belanger B, Chen S, Pan C, Chong C, Cao F, Niekro W, Kempe T, Henning KA, et al. (2013) BMS-936564/MDX-1338: a fully human anti-CXCR4 antibody induces apoptosis in vitro and shows antitumor activity in vivo in hematologic malignancies. Clin Cancer Res 19:357-366.

Kularatne SA, Deshmukh V, Ma J, Tardif V, Lim RK, Pugh HM, Sun Y, Manibusan A, Sellers AJ, Barnett RS, et al. (2014) A CXCR4-targeted site-specific antibodydrug conjugate. Angew Chem Int Ed Engl 53:11863-11867.

Kunik V and Ofran Y (2013) The indistinguishability of epitopes from protein surface is explained by the distinct binding preferences of each of the six antigen-binding loops. Protein Eng Des Sel 26:599-609.

Liu S-H, Gu Y, Pascual B, Yan Z, Hallin M, Zhang C, Fan C, Wang W, Lam J, Spilker $\mathrm{ME}$, et al. (2017) A novel CXCR4 antagonist IgG1 antibody (PF-06747143) for the treatment of hematologic malignancies. Blood Adv 1:1088-1100.

Liu T, Liu Y, Wang Y, Hull M, Schultz PG, and Wang F (2014) Rational design of CXCR4 specific antibodies with elongated CDRs. $J$ Am Chem Soc 136: 10557-10560.

Lonberg N, Taylor LD, Harding FA, Trounstine M, Higgins KM, Schramm SR, Kuo CC, Mashayekh R, Wymore K, McCabe JG, et al. (1994) Antigen-specific human antibodies from mice comprising four distinct genetic modifications. Nature 368: 856-859.

Manglik A and Kobilka B (2014) The role of protein dynamics in GPCR function: insights from the $\beta_{2} \mathrm{AR}$ and rhodopsin. Curr Opin Cell Biol 27:136-143.

Massa S, Vikani N, Betti C, Ballet S, Vanderhaegen S, Steyaert J, Descamps B, Vanhove C, Bunschoten A, van Leeuwen FW, et al. (2016) Sortase A-mediated sitespecific labeling of camelid single-domain antibody-fragments: a versatile strategy for multiple molecular imaging modalities. Contrast Media Mol Imaging 11: $328-339$

Maussang D, Mujić-Delić A, Descamps FJ, Stortelers C, Vanlandschoot P, Stigter-van Walsum M, Vischer HF, van Roy M, Vosjan M, Gonzalez-Pajuelo M, et al. (2013) Llama-derived single variable domains (nanobodies) directed against chemokine receptor CXCR7 reduce head and neck cancer cell growth in vivo. $J$ Biol Chem 288:29562-29572.
Melo RCC, Longhini AL, Bigarella CL, Baratti MO, Traina F, Favaro P, de Melo Campos P, and Saad STO (2014) CXCR7 is highly expressed in acute lymphoblastic leukemia and potentiates CXCR4 response to CXCL12 [published correction appears in PLoS One (2014) 9:e91365]. PLoS One 9:e85926.

Miao Z, Luker KE, Summers BC, Berahovich R, Bhojani MS, Rehemtulla A, Kleer CG, Essner JJ, Nasevicius A, Luker GD, et al. (2007) CXCR7 (RDC1) promotes breast and lung tumor growth in vivo and is expressed on tumor-associated vasculature. Proc Natl Acad Sci USA 104:15735-15740.

Michel MC, Wieland T, and Tsujimoto G (2009) How reliable are G-protein-coupled receptor antibodies? Naunyn Schmiedebergs Arch Pharmacol 379:385-388.

Moore EL and Salvatore CA (2012) Targeting a family B GPCR/RAMP receptor complex: CGRP receptor antagonists and migraine. $\mathrm{Br}$ J Pharmacol 166:66-78.

Mujić-Delić A, de Wit RH, Verkaar F, and Smit MJ (2014) GPCR-targeting nanobodies: attractive research tools, diagnostics, and therapeutics. Trends Pharmacol Sci 35:247-255.

Murphy PM and Heusinkveld L (2018) Multisystem multitasking by CXCL12 and its receptors CXCR4 and ACKR3. Cytokine 109:2-10.

Muyldermans S (2013) Nanobodies: natural single-domain antibodies. Annu Rev Biochem 82:775-797.

Nibbs RJ and Graham GJ (2013) Immune regulation by atypical chemokine receptors. Nat Rev Immunol 13:815-829.

Nuttall SD, Humberstone KS, Krishnan UV, Carmichael JA, Doughty L, Hattarki M, Coley AM, Casey JL, Anders RF, Foley M, et al. (2004) Selection and affinity maturation of IgNAR variable domains targeting Plasmodium falciparum AMA1. Proteins 55:187-197.

Ofran Y, Schlessinger A, and Rost B (2008) Automated identification of complementarity determining regions (CDRs) reveals peculiar characteristics of CDRs and B cell epitopes. J Immunol 181:6230-6235.

Padlan EA (1994) Anatomy of the antibody molecule. Mol Immunol 31:169-217.

Pándy-Szekeres G, Munk C, Tsonkov TM, Mordalski S, Harpsøe K, Hauser AS, Bojarski AJ, and Gloriam DE (2018) GPCRdb in 2018: adding GPCR structure models and ligands. Nucleic Acids Res 46 (D1):D440-D446.

Pardon E, Betti C, Laeremans T, Chevillard F, Guillemyn K, Kolb P, Ballet S, and Steyaert J (2018) Nanobody-enabled reverse pharmacology on G-protein-coupled receptors. Angew Chem Int Ed Engl 57:5292-5295.

Pease J and Horuk R (2012) Chemokine receptor antagonists. J Med Chem 55: 9363-9392

Peled A, Wald O, and Burger J (2012) Development of novel CXCR4-based therapeutics. Expert Opin Investig Drugs 21:341-353.

Peng L, Damschroder MM, Cook KE, Wu H, and Dall'Acqua WF (2016a) Molecular basis for the antagonistic activity of an anti-CXCR4 antibody. MAbs 8:163-175.

Peng SB, Van Horn RD, Yin T, Brown RM, Roell WC, Obungu VH, Ruegg C, Wroblewski VJ, Raddad E, and Stille JR (2017) Distinct mobilization of leukocytes and hematopoietic stem cells by CXCR4 peptide antagonist LY2510924 and monoclonal antibody LY2624587. Oncotarget 8:94619-94634.

Peng SB, Zhang X, Paul D, Kays LM, Ye M, Vaillancourt P, Dowless M, Stancato LF Stewart J, Uhlik MT, et al. (2016b) Inhibition of CXCR4 by LY2624587, a fully humanized anti-CXCR4 antibody induces apoptosis of hematologic malignancies PLoS One 11:e 0150585.

Peyrassol X, Laeremans T, Gouwy M, Lahura V, Debulpaep M, Van Damme J, Steyaert J, Parmentier M, and Langer I (2016) Development by genetic immunization of monovalent antibodies (nanobodies) behaving as antagonists of the human ChemR23 receptor. J Immunol 196:2893-2901.

Polonelli L, Pontón J, Elguezabal N, Moragues MD, Casoli C, Pilotti E, Ronzi P, Dobroff AS, Rodrigues EG, Juliano MA, et al. (2008) Antibody complementaritydetermining regions (CDRs) can display differential antimicrobial, antiviral and antitumor activities. PLoS One 3:e2371.

Putnam FW, Liu YS, and Low TL (1979) Primary structure of a human IgA1 immunoglobulin. IV. Streptococcal IgA1 protease, digestion, Fab and Fc fragments, and the complete amino acid sequence of the $\alpha 1$ heavy chain. J Biol Chem 254: $2865-2874$

Raffaelli B and Reuter U (2018) The biology of monoclonal antibodies: focus on calcitonin gene-related peptide for prophylactic migraine therapy. Neurotherapeutics 15:324-335.

Rajagopal S, Kim J, Ahn S, Craig S, Lam CM, Gerard NP, Gerard C, and Lefkowitz RJ (2010) $\beta$-Arrestin- but not G protein-mediated signaling by the "decoy" receptor CXCR7. Proc Natl Acad Sci USA 107:628-632.

Rasmussen SG, Choi HJ, Fung JJ, Pardon E, Casarosa P, Chae PS, Devree BT, Rosenbaum DM, Thian FS, Kobilka TS, et al. (2011) Structure of a nanobodystabilized active state of the $\beta_{2}$ adrenoceptor. Nature 469:175-180.

Rasmussen SG, Choi HJ, Rosenbaum DM, Kobilka TS, Thian FS, Edwards PC, Burghammer M, Ratnala VR, Sanishvili R, Fischetti RF, et al. (2007) Crysta structure of the human $\beta_{2}$ adrenergic G-protein-coupled receptor. Nature 450: 383-387.

Recke A, Regensburger AK, Weigold F, Müller A, Heidecke H, Marschner G, Hammers CM, Ludwig RJ, and Riemekasten G (2018) Autoantibodies in serum of systemic scleroderma patients: peptide-based epitope mapping indicates increased binding to cytoplasmic domains of CXCR3. Front Immunol 9:428.

Ring AM, Manglik A, Kruse AC, Enos MD, Weis WI, Garcia KC, and Kobilka BK (2013) Adrenaline-activated structure of $\beta_{2}$-adrenoceptor stabilized by an engineered nanobody. Nature 502:575-579.

Rosenkilde MM, Gerlach LO, Hatse S, Skerlj RT, Schols D, Bridger GJ, and Schwartz TW (2007) Molecular mechanism of action of monocyclam versus bicyclam nonpeptide antagonists in the CXCR4 chemokine receptor. J Biol Chem 282: $27354-27365$.

Rosenkilde MM, Gerlach LO, Jakobsen JS, Skerlj RT, Bridger GJ, and Schwartz TW (2004) Molecular mechanism of AMD3100 antagonism in the CXCR4 receptor: transfer of binding site to the CXCR3 receptor. J Biol Chem 279:3033-3041.

Salazar N, Carlson JC, Huang K, Zheng Y, Oderup C, Gross J, Jang AD, Burke TM, Lewén S, Scholz A, et al. (2018) A chimeric antibody against ACKR3/CXCR7 in 
combination with TMZ activates immune responses and extends survival in mouse GBM models. Mol Ther 26:1354-1365.

Saphire EO, Parren PW, Pantophlet R, Zwick MB, Morris GM, Rudd PM, Dwek RA, Stanfield RL, Burton DR, and Wilson IA (2001) Crystal structure of a neutralizing human IgG against HIV-1: a template for vaccine design. Science 293:1155-1159.

Saragovi HU, Fitzpatrick D, Raktabutr A, Nakanishi H, Kahn M, and Greene MI (1991) Design and synthesis of a mimetic from an antibody complementaritydetermining region. Science $\mathbf{2 5 3}: 792-795$

Saxena A and Wu D (2016) Advances in therapeutic Fc engineering-modulation of IgG-associated effector functions and serum half-life. Front Immunol 7:580.

Scholler P, Nevoltris D, de Bundel D, Bossi S, Moreno-Delgado D, Rovira X, Møller TC, El Moustaine D, Mathieu M, Blanc E, et al. (2017) Allosteric nanobodies uncover a role of hippocampal mGlu2 receptor homodimers in contextual fear consolidation. Nat Commun 8:1967.

Scholten DJ, Canals M, Maussang D, Roumen L, Smit MJ, Wijtmans M, de Graaf C, Vischer HF, and Leurs R (2012) Pharmacological modulation of chemokine receptor function. Br J Pharmacol 165:1617-1643.

Schwickart M, Chavez C, Henderson S, Vainshtein I, Standifer N, DelNagro C, Mehrzai F, Schneider A, Roskos L, and Liang M (2016) Evaluation of assay interference and interpretation of CXCR4 receptor occupancy results in a preclinical study with MEDI3185, a fully human antibody to CXCR4. Cytometry B Clin Cytom 90:209-219.

Sela-Culang I, Kunik V, and Ofran Y (2013) The structural basis of antibody-antigen recognition. Front Immunol 4:302.

Sheridan C (2017) Ablynx's nanobody fragments go places antibodies cannot. Nat Biotechnol 35:1115-1117.

Shi L, Lehto SG, Zhu DX, Sun H, Zhang J, Smith BP, Immke DC, Wild KD, and Xu C (2016) Pharmacologic characterization of AMG 334, a potent and selective human monoclonal antibody against the calcitonin gene-related peptide receptor. $J$ Pharmacol Exp Ther 356:223-231.

Silberstein S, Lenz R, and Xu C (2015) Therapeutic monoclonal antibodies: what headache specialists need to know. Headache 55:1171-1182.

Silence K, Dreier T, Moshir M, Ulrichts P, Gabriels SM, Saunders M, Wajant H, Brouckaert P, Huyghe L, Van Hauwermeiren T, et al. (2014) ARGX-110, a highly potent antibody targeting CD70, eliminates tumors via both enhanced ADCC and immune checkpoint blockade. MAbs 6:523-532.

Smith SL (1996) Ten years of orthoclone OKT3 (muromonab-CD3): a review. $J$ Transpl Coord 6:109-119, quiz 120-121.

Sriram K and Insel PA (2018) G protein-coupled receptors as targets for approved drugs: how many targets and how many drugs? Mol Pharmacol 93:251-258.

Staus DP, Wingler LM, Strachan RT, Rasmussen SG, Pardon E, Ahn S, Steyaert J, Kobilka BK, and Lefkowitz RJ (2014) Regulation of $\beta_{2}$-adrenergic receptor function by conformationally selective single-domain intrabodies. Mol Pharmacol 85:472-481.

Stoeber M, Jullié D, Lobingier BT, Laeremans T, Steyaert J, Schiller PW, Manglik A and von Zastrow M (2018) A genetically encoded biosensor reveals location bias of opioid drug action. Neuron 98:963-976.e5.

Streltsov VA, Varghese JN, Carmichael JA, Irving RA, Hudson PJ, and Nuttall SD (2004) Structural evidence for evolution of shark Ig new antigen receptor variable domain antibodies from a cell-surface receptor. Proc Natl Acad Sci USA 101: 12444-12449.

Tamamura H, Fujisawa M, Hiramatsu K, Mizumoto M, Nakashima H, Yamamoto N, Otaka A, and Fujii N (2004) Identification of a CXCR4 antagonist, a T140 analog, as an anti-rheumatoid arthritis agent. FEBS Lett 569:99-104.

Tamura T and Chiba J (2009) Production of antibodies against multipass membrane proteins expressed in human tumor cells using dendritic cell immunization. J Biomed Biotechnol 2009:673098.
Teixidó J, Martínez-Moreno M, Díaz-Martínez M, and Sevilla-Movilla S (2018) The good and bad faces of the CXCR4 chemokine receptor. Int J Biochem Cell Biol 95: 121-131.

Thiele S, Mungalpara J, Steen A, Rosenkilde MM, and Våbenø J (2014) Determination of the binding mode for the cyclopentapeptide CXCR4 antagonist FC131 using a dual approach of ligand modifications and receptor mutagenesis. $\mathrm{Br}$ J Pharmacol 171:5313-5329.

van der Woning B, De Boeck G, Blanchetot C, Bobkov V, Klarenbeek A, Saunders M, Waelbroeck M, Laeremans T, Steyaert J, Hultberg A, et al. (2016) DNA immunization combined with $\mathrm{scFv}$ phage display identifies antagonistic GCGR specific antibodies and reveals new epitopes on the small extracellular loops. MAbs 8: 1126-1135.

Van Hout A, Klarenbeek A, Bobkov V, Doijen J, Arimont M, Zhao C, Heukers R, Rimkunas R, de Graaf C, Verrips T, et al. (2018) CXCR4-targeting nanobodies differentially inhibit CXCR4 function and HIV entry. Biochem Pharmacol 158: $402-412$

Venkatakrishnan AJ, Deupi X, Lebon G, Tate CG, Schertler GF, and Babu MM (2013) Molecular signatures of G-protein-coupled receptors. Nature 494:185-194.

Vidarsson G, Dekkers G, and Rispens T (2014) IgG subclasses and allotypes: from structure to effector functions. Front Immunol 5:520.

Walker CS, Eftekhari S, Bower RL, Wilderman A, Insel PA, Edvinsson L, Waldvoge HJ, Jamaluddin MA, Russo AF, and Hay DL (2015) A second trigeminal CGRP receptor: function and expression of the AMY1 receptor. Ann Clin Transl Neurol 2: $595-608$

Wallukat G and Schimke I (2014) Agonistic autoantibodies directed against G-protein-coupled receptors and their relationship to cardiovascular diseases. Semin Immunopathol 36:351-363.

Wang C, Chen W, and Shen J (2018) CXCR7 targeting and its major disease relevance. Front Pharmacol 9:641.

Webb B and Sali A (2017) Protein structure modeling with MODELLER. Methods Mol Biol 1654:39-54.

Weigold F, Günther J, Pfeiffenberger M, Cabral-Marques O, Siegert E, Dragun D, Philippe A, Regensburger A-K, Recke A, Yu X, et al. (2018) Antibodies against chemokine receptors CXCR3 and CXCR4 predict progressive deterioration of lung function in patients with systemic sclerosis. Arthritis Res Ther 20:52.

Wu H and Dall'Acqua WF (2005) Humanized antibodies and their applications. Methods 36:1-2.

Xu C, Sui J, Tao H, Zhu Q, and Marasco WA (2007) Human anti-CXCR4 antibodies undergo VH replacement, exhibit functional V-region sulfation, and define CXCR4 antigenic heterogeneity. J Immunol 179:2408-2418.

Zabel BA, Wang Y, Lewén S, Berahovich RD, Penfold ME, Zhang P, Powers J, Summers BC, Miao Z, Zhao B, et al. (2009) Elucidation of CXCR7-mediated signaling events and inhibition of CXCR4-mediated tumor cell transendothelial migration by CXCR7 ligands. J Immunol 183:3204-3211.

Zhang Y, Saavedra E, Tang R, Gu Y, Lappin P, Trajkovic D, Liu SH, Smeal T, Fantin V, De Botton S, et al. (2017) Targeting primary acute myeloid leukemia with a new CXCR4 antagonist IgG1 antibody (PF-06747143). Sci Rep 7:7305.

Address correspondence to: Martine J. Smit, Division of Medicinal Chemistry, Amsterdam Institute for Molecules, Medicines and Systems, Vrije Universiteit Amsterdam, Amsterdam, De Boelelaan 1108, 1081 HZ Amsterdam, The Netherlands. E-mail: mj.smit@vu.nl 